\title{
Livelihood strategies, capital assets, and food security in rural Southwest Ethiopia
}

\author{
Aisa O. Manlosa ${ }^{1}$ (D) Jan Hanspach ${ }^{1} \cdot$ Jannik Schultner ${ }^{1} \cdot$ Ine Dorresteijn $^{2} \cdot$ Joern Fischer $^{1}$
}

Received: 29 December 2017 / Accepted: 20 December 2018 / Published online: 24 January 2019

(C) The Author(s) 2019

\begin{abstract}
Households combine capital assets in a process involving human agency and resourcefulness to construct livelihood strategies and generate well-being outcomes. Here, we (1) characterized types of livelihood strategies; (2) determined how different capital assets are associated with different livelihood strategies; and (3) determined how livelihood strategies differed in food security outcomes. We conducted a survey in southwestern Ethiopia and used principal component and cluster analyses. Five types of livelihood strategies, which differed mainly in food and cash crops comprising the strategy, were identified. These were, in order of decreasing food security: 'three food crops, coffee and khat', $n=68$; 'three food crops and khat', $n=59$; 'two food crops, coffee and khat', $n=78$; 'two food crops and khat', $n=88$; and 'one food crop, coffee and khat', $n=44$. The livelihood strategy 'three food crops, coffee and khat' was associated with a wide range of capital assets, particularly having larger aggregate farm field size and learning from other farmers. A generalized linear model showed that livelihood strategies were significantly associated with food security outcomes. Particularly, a high number of food crops in a strategy was linked with relatively high food security. In this context, diversified livelihood strategies primarily through having a mix of food crops for subsistence, in combination with cash crops for income, are important for food security. This suggests a need to rethink dominant policy narratives, which have a narrow focus on increasing productivity and commercialization as the primary pathway to food security.
\end{abstract}

Keywords Livelihood strategies $\cdot$ Food policies $\cdot$ Smallholder farming $\cdot$ Agriculture $\cdot$ Diversification $\cdot$ Ethiopia

\section{Introduction}

Electronic supplementary material The online version of this article (https://doi.org/10.1007/s12571-018-00883-x) contains supplementary material, which is available to authorized users.

Aisa O. Manlosa

aisamanlosa@gmail.com

Jan Hanspach

hanspach@leuphana.de

Jannik Schultner

jannik.schultner@leuphana.de

Ine Dorresteijn

ine.dorresteijn@gmail.com; i.dorresteijn@uu.nl

Joern Fischer

joern.fischer@uni.leuphana.de

1 Faculty of Sustainability, Leuphana University Lueneburg, Lueneburg, Germany

2 Copernicus Institute of Sustainable Development, Utrecht University, Utrecht, Netherlands
Driven by global change, livelihood strategies in agricultural landscapes are evolving in developing countries around the world. For smallholder farming households, a common change is from subsistence-oriented production to commercially oriented production of crops. Such a shift is actively encouraged by some governments (see e.g. Gebrehiwot et al. 2016; Vongvisouk et al. 2014) on the grounds that it will improve food security through economic growth. However, outcomes of such a change have been mixed so that the ways in which different livelihood strategies influence household food security in different settings is less clear (Lang and Barling 2012). Understanding how livelihood strategies, particularly different combinations of food crops and cash crops, influence the food security of smallholder farming households is important for identifying and supporting sustainable development trajectories of traditionally subsistence-oriented or semi-subsistent agricultural landscapes.

For smallholder farming households, two plausible pathways of crop production have been advocated to 
increase food security, namely: (1) cash crop production (e.g. Achterbosch et al. 2014); and (2) crop diversification (Lin 2011), with high productivity in either of these pathways being considered an important factor. Maxwell and Fernando (1989) defined cash crops as all marketed surplus, non-staple agriculture, non-food agriculture, and export agriculture. Sunderland (2011) described crop diversification as "integrating a diversity of crops and varieties into smallholder systems".

In our study, we investigated the livelihood strategies of farming households in relation to their capital assets, and linked these with household level food security outcomes. We considered different combinations of livelihood activities, which, in the context studied, primarily consisted of food crops and cash crops. We focused on Ethiopia where, in 2015 , about $81 \%$ of the population lived in rural areas and mainly relied on agriculture for their livelihoods (World Bank 2016). We selected southwest Ethiopia, an area with high biodiversity, large tracts of Afromontane forests (Hylander et al. 2013), and home to the wild gene pool of Arabica coffee (Coffea arabica), which generates the largest foreign exchange for the country (FAO 2016). Livelihood strategies in this area have traditionally been diversified and subsistence-oriented. However, the government's Growth and Transformation Plan II aims "to transform... from subsistence to more commerciallyoriented agriculture" through various means including increasing coffee production, agricultural intensification and orientation of certain crops for markets (Ethiopia National Planning Commission 2016). Within government circles, this trajectory from subsistence to commercial orientation is perceived as promising potential benefits for food security. Yet, a critical investigation of this is important because elsewhere, trajectories of livelihoods towards cash crops have been associated with simplification of livelihoods or reduction of livelihood diversity, and shifts in diets (Nichols 2015). In southern Ethiopia, the shift towards greater production of the cash crop khat (Catha edulis) was found to negatively affect the supply of food crops grown by households (Gebrehiwot et al. 2016).

Against this context of changing livelihoods and government incentives, our objectives were to (1) develop an empirically grounded characterization of existing livelihood strategies in the study area; (2) determine how different types of capital asset are associated with different livelihood strategies; and (3) examine how the identified livelihood strategies differ in terms of food security outcomes. Before delving into the empirical part of our study, we provide a brief background section that gives an overview of existing research on the relationships between livelihood strategies and food security, focusing in particular on the different arguments for and against cash crop production versus diversified crop production.

\section{Background on the relationships between livelihoods and food security}

Determining how food security can be achieved has been a long-standing subject of scholarly and policy debates. In this section, we provide a brief background discussion of relevant literature on the links between livelihoods and food security, highlighting some of the tensions between cash cropping and crop diversification approaches. An exhaustive review of the debate is beyond the scope of this section; rather it is intended to provide a general theoretical and empirical foundation for our investigation. We first outline developments in livelihoods research and then transition into the more specific debate on how different kinds of livelihoods relate to food security.

Sustainable livelihoods thinking has contributed rich understandings of the ways individuals, households, and social groups in different contexts exercise agency and use their capital assets to produce outcomes necessary for sustenance and well-being (de Haan and Zoomers 2006; Levine 2014). The seminal work by Chambers and colleagues (Chambers 1987; Chambers and Ghildyal 1985; Chambers and Conway 1992) emphasized placing people at the center of scientific inquiry into poverty, food security, and environmental degradation and gave rise to livelihoods thinking. Subsequently, certain principles of livelihoods thinking were operationalized through the formulation of the Sustainable Livelihoods Framework (Carney 1999; Scoones 1998), or in short, the "livelihoods approach". The livelihoods approach has been widely used for systematically analyzing livelihoods and their relationships with well-being outcomes, both in rural and urban areas. Often, the critical question is how different livelihood strategies generate different outcomes for individuals, households, or groups in terms of incomes, nutrition, caloric intake, or other wellbeing measures (e.g. Frison et al. 2011; Martin et al. 2013). In rural areas particularly, the multi-faceted nature of agricultural livelihoods, the dynamism of contexts, temporality, and the element of human agency responding to and acting on accessible capital assets make it challenging to generalize which livelihood strategies generate the best outcomes for human well-being. Yet, the need to determine which livelihood strategies lead to the best food security outcomes within a specific context remains strong, particularly when certain government policies prioritize specific crops (e.g. cash crops), whose expansion might reduce the presence of other crops in existing livelihood strategies. A better understanding of the food security outcomes associated with different livelihood strategies is particularly important in semi-subsistence landscapes. Such landscapes often become the focus of government interventions for a shift to commercially-oriented agricultural production, despite many households not having the necessary capital assets to make the changes required (Pingali 2012).

Improving food security through the cash crop pathway is premised on the production and marketing of cash crops (or of 
commercially-oriented food crops) to generate financial income that farming households can use not only to purchase food, but also to accumulate capital assets necessary for further improving their livelihoods (Govereh and Jayne 2003). This pathway ultimately aims to address poverty, which is an important cause of food insecurity (Smith et al. 2000). Cotton production in Gokwe North District, Zimbabwe (Govereh and Jayne 2003) and palm oil production in Indonesia (Sayer et al. 2012) exemplify the potential economic benefits (and indirectly food security benefits) resulting from intensive engagement in cash crop production. However, consequences are not always positive particularly for the poor; and diverging outcomes have been observed for different community groups. For example, the cash crop sugarcane was found to have a positive effect on food security in Ethiopia, but cotton production in Ghana resulted in lower food security among growers (Lam et al. 2017). In Sulawesi, Indonesia, Belsky and Siebert (2003) found that food self-sufficiency would likely decline with conversion of food-crop focused swidden fields to cocoa farms. In northern Vietnam, intensified and commercialized agriculture linked with cash crops also suggested the emergence of "new food insecurities and vulnerabilities" (Bonnin and Turner 2012). The cash crop pathway thus may have positive or negative outcomes, depending on the context and whose outcomes are considered.

The crop diversification pathway may benefit food and nutrition security primarily by enabling households to have direct access to staples and other types of food crops (Jones et al. 2014; Powell et al. 2015). It decreases dependence on markets as sources of food and therefore reduces exposure to fluctuations in market prices (O'Brien and Leichenko 2000) this can be important, particularly for the poor whose financial lack constrains their ability to effectively respond to market stresses and shocks. Food crop diversification also enables households to spread risks over different crop types so that failure in one does not lead to the collapse of the entire livelihood strategy (Ellis 2000). In the Bolivian Andes, production of diverse food crops for subsistence was found to be a plausible approach for improving household and children's diets (Jones 2014). In Kenya, agricultural diversity consisting mostly of food crops was positively related to nutrient adequacy ratios (M'Kaibi et al. 2015). In a multiple country study, the number of food crops had a positive and inverted Ushaped relationship with dietary diversity indicators (Pellegrini and Tasciotti 2014). That is, dietary diversity increased with crop diversity up to a point and then began to decrease. However, in most studies it remains unclear whether the positive effects of crop diversification resulted directly from consumption of the food crops, or through selling them.

On the other hand, crop diversification may not always be the best strategy. Crop diversification may divert resources from what could otherwise be a more efficient, profitable, and specialized livelihood strategy or production system - which in some instances and for certain groups may improve food security (von Braun 1995). Subsistence-based diversification strategies also do not primarily facilitate income generation. This is important because higher income from agricultural production has been found to be associated with improved food security (e.g. Salazar et al. 2015). Similarly, Sibhatu and Qaim (2018) found that subsistence production contributed less to dietary diversity than cash income. Such mixed outcomes across different contexts suggest that pathways towards food security need to be grounded in a contextualized understanding of existing livelihood strategies.

The construction of livelihood strategies can be seen as the outcome of an actively negotiated process where households consider available capital assets, achievable household goals, and options for realizing these goals within the limits of capital assets (Rakodi 1999). Analyzing existing livelihood strategies and outcomes in a specific context is primal because context shapes the opportunity structures within which livelihoods are constructed (Bebbington 1999). For example, how well an area is connected to markets, and the extent to which transportation facilities are accessible, may influence the livelihood strategies in an area (Acheampong et al. 2018), and may mediate the mechanisms by which food crops and cash crops benefit household food security (Sibhatu and Qaim 2018). Moreover, the ability of households to engage in a type of livelihood strategy is influenced by the types of capital assets they have access to (Scoones 1998; Rakodi 1999). We hypothesized that differentiated access to capital assets such as land, livestock and social capital enable or constrain types of livelihood strategies.

\section{Material and methods}

\subsection{Study area and field sampling}

We studied six kebeles (smallest administrative unit in Ethiopia) situated in three woredas, or districts, in Jimma Zone, Oromia Region, Ethiopia. Kebeles were selected along an altitude and forest cover gradient to capture a variety of livelihood strategies (Online Resource 1). The highlands of southwest Ethiopia receive an average of $2275 \mathrm{~mm}$ of annual rainfall, with a rainy period from February to November (Kidanewold et al. 2014). By international standards, food security is low (Ethiopia CSA and WFP 2014) particularly during the lean season from June to August every year. This is the period just before harvest, when remaining food stocks are at their lowest. The number of households in the kebeles ranged from 322 to 1222 . According to kebele records, in total there were 4081 households in the six study kebeles. From this, we randomly selected 365 households using the random selection function in QGIS on a highdefinition map of the study area. 


\subsection{Survey tool and concepts used}

We used a survey questionnaire for data collection. This was implemented with the assistance of two trained enumerators. The survey tool was translated into the local language Aafan Oromo and back-translated to English to ensure that the integrity of the original meaning was maintained. It was pre-tested in a pilot study in August 2015, and revised before the data collection period, which ran from November 2015 to January 2016. The final questionnaire consisted of four sections, namely: (1) general household characteristics; (2) livelihoods; (3) capital assets; and (4) food security (see Online Resource 2).

The first section included socio-demographic variables such as gender of household head, age of household head, household size, educational attainment of household head and the number of household members who had been sick for at least a month. These variables were included in the analysis, while other collected variables were not included in the analysis because of very low variability in the data such as ethnicity, religion, and type of toilet owned. The second and third sections were guided by the Sustainable Livelihoods Framework. We defined livelihoods as being comprised of the strategies and assets required to make a living (Scoones 1998). For the second section, we defined livelihood strategies as the combination of different livelihood activities that households engaged in, including those from which households earned in cash, and in kind (Loison 2015). We asked about all types of livelihood activities to determine the composition of livelihood strategies. Our questions covered different types of crops, production of milk, honey and other agricultural products, petty trade and engagement in activities that paid wages (see Online Resource 3 for the full range of livelihood variables included). Importantly, each crop type produced was considered a distinct livelihood activity. For the third section, we considered capital assets as the building blocks from which households constructed livelihood strategies. Here, questions related to various capital asset variables belonging to one of five capital asset types (i.e. economic, human, natural, physical, and social). Some examples under economic capital assets were access to credit and having a coffee plot. For human capital, we included questions on health and access to information or knowledge through formal or informal channels (Table 1). The fourth section on food security was a modified version of the Household Food Insecurity Access Scale (HFIAS) (Coates et al. 2007; Maxwell et al. 2013). Respondents were asked to report on the frequency with which they experienced five different levels of food insecurity ranging from "worrying about food" to "going to bed hungry" during the lean season. The frequency of each experience was scored: zero (not experienced), one (rarely, about once or twice a month), two (sometimes, about three to ten times a month), or three (often, estimated more than ten times a month). The scores enabled us to derive a total HFIAS score ranging from 0 to 15 for each household, with smaller values indicating high food security and higher values indicating low food security. Between two months and five months had passed since the end of the lean season from the first household to the last household surveyed. This recall period was longer than used in most other studies. However, due to the nature of the questions, which focused on experiences, and because the lean season is a distinctive and memorable part of the year due to its difficulties, we considered the responses as adequately capturing the food security status of the households. To statistically confirm this, we designed our model to detect effects from temporal proximity of each survey date to the lean period, by incorporating survey date as a variable in the model used (see below). Modified versions of the HFIAS have been found to be robust tools for assessessing food security in other parts of Ethiopia (Gebreyesus et al. 2015). The survey was implemented such that the first half of the sample in each kebele was completed during the first half of the field work. We then returned to every kebele to complete the survey in the second half of the field work. In addition to the survey, we also took field notes to record qualitative observations concerning the broader context such as physical infrastructure, market access, and livelihood problems, and gained insights from informal conversations with local residents.

\subsection{Data analysis}

We processed the data in $\mathrm{R}$ ( $\mathrm{R}$ Development Core Team 2008). As a first step, we explored the distribution and variability of data. Variables with very low variability across the households were excluded from the analysis. For the variables that were selected for inclusion in the analysis, we identified cells with missing data and applied an imputation process called multiple imputation chained equations through the 'mice' package in $\mathrm{R}$ (Van Buuren and Groothuis-Oudshoorn 2011). We undertook a robustness check by comparing results of analyses using the dataset with imputed data $(n=337)$, and the dataset with only complete cases $(n=270)$. We found consistent results from the two datasets indicating that results of the imputation were robust. A total of 337 questionnaires were used for the final analysis. We then visually inspected distributions of the continuous data and log-transformed skewed variables to meet requirements of normality for multivariate analyses.

Qualitative data from field notes were used to provide a descriptive background of the local context. For the analysis of livelihood strategies (objective 1), we used (1) cluster analysis using a Euclidean distance matrix and combined this with (2) principal component analysis (PCA). ${ }^{1}$ We applied Ward

\footnotetext{
${ }^{1}$ Analysis involved continuous harvest data for all main crops except khat for which we were limited to using presence-absence data due to a lack of reliable data on both harvest and income. We ran PCA analysis without the variable khat to check robustness of results. We found that results with and without khat were very similar (correlation in a symmetric Procrustes rotation of 0.9962). This suggests that including khat as a binomial variable did not unduly influence the results.
} 
Table 1 List of capital asset variables included in analysis and how each variable was measured

\begin{tabular}{|c|c|c|}
\hline $\begin{array}{l}\text { Type of capital } \\
\text { asset }\end{array}$ & Variable & Measurement \\
\hline \multirow[t]{3}{*}{ Economic } & Access to credit & $0-$ No, $1-$ Yes \\
\hline & Ownership of coffee plot & $0-$ No, $1-$ Yes \\
\hline & Ownership of khat plot & $0-\mathrm{No}, 1-\mathrm{Yes}$ \\
\hline \multirow[t]{26}{*}{ Human } & Learning farming-related information from development agents & $0-\mathrm{No}$ \\
\hline & & Yes, \\
\hline & & Frequency \\
\hline & & 1 - Rarely \\
\hline & & 2 - Seldom \\
\hline & & 3 - Often \\
\hline & Learning farming-related information from other farmers, & $0-$ No \\
\hline & & Yes, \\
\hline & & Frequency \\
\hline & & 1 - Rarely \\
\hline & & 2 - Seldom \\
\hline & & 3 - Often \\
\hline & Family farm labor & Number of family members that help in the farm \\
\hline & Access to information about new technology and market prices & $0-\mathrm{No}$ \\
\hline & & Yes, \\
\hline & & Frequency \\
\hline & & 1 - Rarely \\
\hline & & 2 - Seldom \\
\hline & & $3-$ Often \\
\hline & Highest educational attainment of household head & 0 - No education \\
\hline & & 1 - Adult education or special education \\
\hline & & 2 - Grades 1 to 6 \\
\hline & & 3 - Grades 7 to 12 \\
\hline & & 4 - Grades 13 and above \\
\hline & Health using as proxy presence or absence of household members & $1-$ Yes \\
\hline & who got sick continuously for more than a month in the last one year & $0-$ No \\
\hline \multirow[t]{10}{*}{ Natural } & Access to surrounding natural resources such as forests and water & $0-\mathrm{No}, 1-\mathrm{Yes}$ \\
\hline & $\begin{array}{l}\text { Perception on environmental change in the immediate landscape, } \\
\text { whether positive or negative }\end{array}$ & $\begin{array}{l}0 \text { - No change or worsening } \\
1 \text { - Improving }\end{array}$ \\
\hline & Perception on soil fertility & $0-\mathrm{Bad}$ \\
\hline & & $1-$ Medium \\
\hline & & $2-$ Good \\
\hline & Access to trees for the production of honey & $0-$ No, $1-$ Yes \\
\hline & Access to eucalyptus & $0-\mathrm{No}, 1-\mathrm{Yes}$ \\
\hline & Size of farm fields & Total size in hectares \\
\hline & Size of home garden & Total size in hectares \\
\hline & Land rights (whether having a land certificate or not) & $0-$ No, $1-$ Yes \\
\hline \multirow[t]{4}{*}{ Physical } & Length of travel time to get from house to market & Minutes \\
\hline & Livestock and poultry owned & Number of livestock and poultry \\
\hline & Mobile phone owned & Number of mobile phones \\
\hline & Farm tools owned & Number of farm tools \\
\hline \multirow[t]{6}{*}{ Social } & Membership to farming organization & $0-$ No, $1-$ Yes \\
\hline & $\begin{array}{l}\text { Presence or absence of individuals or organizations to turn to for } \\
\text { help with livelihood problems }\end{array}$ & $0-$ No, $1-$ Yes \\
\hline & $\begin{array}{l}\text { Presence or absence of individuals or organizations to turn to for } \\
\text { help with shortage in food or cash income }\end{array}$ & $0-$ No, $1-$ Yes \\
\hline & Ability to speak out regarding management of nearby natural resources & $0-$ No, $1-$ Yes \\
\hline & Sharing or borrowing of livestock & $\begin{array}{l}\text { Number of livestock used (i. e. for farming) which } \\
\text { was either borrowed or within a livestock-sharing } \\
\text { arrangement }\end{array}$ \\
\hline & Sharecropping & $\begin{array}{l}\text { Number of crops that were produced through sharecropping } \\
\text { arrangements }\end{array}$ \\
\hline
\end{tabular}

hierarchical clustering because this yielded a clear group structure and better interpretability of results than other clustering methods. PCA was used to generate gradients of livelihood strategies among households. Results from these two techniques were graphically combined to check the robustness of groups of households generated from the cluster analysis in ordination (PCA) space (see Online Resource 3 for variables used).

Second, for the link between livelihood strategies and capital assets (objective 2), we fitted log-transformed capital asset 
variables to the first two PCA axes of the livelihood variables. Specifically, using the 'envfit' function in R (Oksanen et al. 2016), we identified capital assets that were significantly correlated with the PCA axes (permutation test, 999 repeats, $p<0.01)$. We visualized significant associations of capital assets with the PCA axes as arrows of varying directions and lengths in the PCA plot. This enabled us to interpret the association of different types of capital assets with different livelihood strategies. As a further step, using multinomial logistic regression, we tested for relationships between livelihood strategies as a categorical response variable against capital asset variables with significant associations from the envfit analysis (multinom function from the nnet package) (Venables and Ripley 2002). Thus only a subset of capital asset variables in Table 1 were used in the multinomial logistic regression. We emphasize that, like all regression models, this analysis helped to uncover significant associations between livelihood strategies and capital assets, but was not a direct test of causal links.

Third, to determine whether food security measured through HFIAS scores responded significantly to the types of livelihood strategies and socio-demographic variables such as the gender of household head, age, household size, number of ill household members, and educational attainment of the household head (objective 3), we ran a generalized linear model using a quasi-Poisson error distribution to account for overdispersion. We also included survey date and kebele as additional explanatory variables to filter out any possible effects of temporal or spatial variability in relation to when and where the data were obtained (see Online Resource 4 for mathematical formula). Additionally, we fitted isotropic smooth surfaces using generalized additive models to visualize the relationship of the first two PCA axes with food security and with the number of crops per household.

\section{Results}

\subsection{Description of local context}

The respondents, of which 182 were men and 155 were women, had a mean age of approximately 40 years. On average, they attended school for between 1 and 6 years. Households had an average of six members (see Table 2 for household characteristics by livelihood strategy). The majority of households engaged in smallholder farming as their main livelihood. The most common livelihood activities involved production of food crops namely maize, sorghum and teff. Barley and wheat were also produced but in lower quantities (Table 3). These food crops were produced mainly for subsistence, with a range of 93-100\% of harvest reported as used for consumption. The crops coffee and khat were the main sources of cash. Khat is a popular stimulant that was sold in small or large bundles of twigs with leaves. There were other livelihood activities in the area including the cultivation of home gardens, production of legumes, production of milk, cheese, butter and honey for household consumption and the local market, selling firewood, selling eucalyptus trees, and engagement in farm labor and non-farm labor for wages.

Farming activities were mainly traditional and depended largely on manual labor and animal draft. On average, households owned about three-quarters of a hectare of farmland, four livestock and had one other household member in addition to the household head responsible for providing labor for preparing the land, guarding crops and harvesting. Common livelihood problems such as lack of farmland, livestock and labor were typically addressed through sharecropping arrangements. An average of two fields for each household were sharecropped fields. Most households had limited connection to markets either for selling their produce or purchasing goods. At the kebele level, there were two types of markets. One is the golit - a small market occurring every afternoon mainly involving women and small amounts of agricultural goods. The gaba is a larger market occurring once a week, involving both men and women. On average it took $103 \mathrm{~min}$ to get from the house to a kebele's main market area. Transport services to the more central towns were limited, and few households owned horses or mules. Access to credit was also limited. Some households used informal credit channels such as borrowing coffee or cash from neighbors, friends or kin to address shortfalls.

\subsection{Typologies of livelihood strategies}

Different combinations of cash crops and food crops distinctively defined the livelihood strategies of households. Households typically produced multiple crops, three on average. Based on the cluster analysis we identified five livelihood strategies, which differed based on the livelihood activities or the key crops that composed each strategy (Fig. 1; also see Online Resource 5 for dendrogram). In the order of best to worst food security outcomes, the first livelihood strategy was characterized mainly by the food crops maize, teff and sorghum, and cash crops coffee and khat ('three food crops, coffee and khat', $n=68$ ). This was followed by the strategy consisting mainly of food crops maize, teff and sorghum, and khat ('three food crops and khat', $n=59$ ). These two strategies with the best food security outcomes notably included three food crops, with the difference of the first strategy having two cash crops and the second having only one cash crop.

The next strategy consisted mainly of the food crops maize and teff, and involved coffee and khat ("two food crops, coffee and khat', $n=78$ ). This was followed by the strategy consisting mainly of maize, teff and khat ('two food crops and khat, $n=88$ ). The final livelihood strategy with the lowest food security had only maize as food crop, and coffee and khat ('one food crop, coffee and khat', $n=44$ ). Additional marginal 
Table 2 Household characteristics and capital assets summarized by livelihood strategy

\begin{tabular}{|c|c|c|c|c|c|}
\hline Variables (mean \pm standard deviation where applicable) & $\begin{array}{l}\text { Three food crops, } \\
\text { coffee and khat }\end{array}$ & $\begin{array}{l}\text { Three food } \\
\text { crops and khat }\end{array}$ & $\begin{array}{l}\text { Two food crops, } \\
\text { coffee and khat }\end{array}$ & $\begin{array}{l}\text { Two food } \\
\text { crops and khat }\end{array}$ & $\begin{array}{l}\text { One food crop, } \\
\text { coffee and khat }\end{array}$ \\
\hline \multicolumn{6}{|l|}{ Household characteristics } \\
\hline $\begin{array}{l}\text { Household type (proportion of FHH - female-headed } \\
\text { households, MHH - male-headed households) }\end{array}$ & $\begin{array}{l}\text { FHH }-9 \\
\text { MHH }-91\end{array}$ & $\begin{array}{l}\text { FHH }-8 \\
\text { MHH }-92\end{array}$ & $\begin{array}{l}\text { FHH }-6 \\
\text { MHH }-94\end{array}$ & $\begin{array}{l}\text { FHH }-8 \\
\text { MHH }-92\end{array}$ & $\begin{array}{l}\text { FHH }-7 \\
\text { MHH }-93\end{array}$ \\
\hline Age of household head (yrs) & $41 \pm 16$ & $40 \pm 15$ & $44 \pm 16$ & $39 \pm 15$ & $41 \pm 16$ \\
\hline Education of household head (ordinal categories) & $1 \pm 1$ & $1 \pm 1$ & $0.6 \pm 0.9$ & $1 \pm 1$ & $1 \pm 1$ \\
\hline Household size (nr) & $6.2 \pm 2.9$ & $6.5 \pm 2.8$ & $6.1 \pm 2.5$ & $5.9 \pm 2.4$ & $5.8 \pm 2.3$ \\
\hline Ill health members (nr) & $0.3 \pm 0.6$ & $0.3 \pm 0.5$ & $0.4 \pm 0.6$ & $0.4 \pm 0.7$ & $0.3 \pm 0.5$ \\
\hline \multicolumn{6}{|l|}{ Capital assets } \\
\hline Ownership of coffee plot (proportion of yes/no) & $\begin{array}{l}\text { Yes }-99 \\
\text { No }-1\end{array}$ & $\begin{array}{l}\text { Yes }-22 \\
\text { No }-78\end{array}$ & $\begin{array}{l}\text { Yes }-100 \\
\text { No }-0\end{array}$ & $\begin{array}{l}\text { Yes }-20 \\
\text { No }-80\end{array}$ & $\begin{array}{l}\text { Yes }-91 \\
\text { No }-9\end{array}$ \\
\hline Total size of farm fields (ha) & $0.9 \pm 0.5$ & $1.1 \pm 0.7$ & $0.8 \pm 0.4$ & $0.7 \pm 0.3$ & $0.3 \pm 0.3$ \\
\hline Sharecropped fields (nr) & $1.5 \pm 1.3$ & $2.2 \pm 1.4$ & $1.6 \pm 1.1$ & $1.7 \pm 1.3$ & $0.5 \pm 0.7$ \\
\hline Livestock owned (nr) & $3.2 \pm 2.6$ & $5.1 \pm 4.5$ & $3.6 \pm 2.6$ & $4.0 \pm 3.1$ & $2.0 \pm 1.2$ \\
\hline $\begin{array}{l}\text { Learn from other farmers } \\
\text { (proportion according to frequency) }\end{array}$ & $\begin{array}{l}\text { Never }-35 \\
\text { Rarely }-22 \\
\text { Seldom }-22 \\
\text { Often }-21\end{array}$ & $\begin{array}{l}\text { Never }-42 \\
\text { Rarely }-17 \\
\text { Seldom }-25 \\
\text { Often }-15\end{array}$ & $\begin{array}{l}\text { Never }-53 \\
\text { Rarely }-14 \\
\text { Seldom }-20 \\
\text { Often }-13\end{array}$ & $\begin{array}{l}\text { Never }-60 \\
\text { Rarely }-8 \\
\text { Seldom }-26 \\
\text { Often }-6\end{array}$ & $\begin{array}{l}\text { Never }-64 \\
\text { Rarely }-11 \\
\text { Seldom }-16 \\
\text { Often }-9\end{array}$ \\
\hline $\begin{array}{l}\text { Learn from development agents } \\
\text { (proportion according to frequency) }\end{array}$ & $\begin{array}{l}\text { Never }-26 \\
\text { Rarely }-25 \\
\text { Seldom }-37 \\
\text { Often }-12\end{array}$ & $\begin{array}{l}\text { Never }-46 \\
\text { Rarely }-22 \\
\text { Seldom }-22 \\
\text { Often }-10\end{array}$ & $\begin{array}{l}\text { Never }-37 \\
\text { Rarely }-21 \\
\text { Seldom }-22 \\
\text { Often }-20\end{array}$ & $\begin{array}{l}\text { Never }-52 \\
\text { Rarely }-19 \\
\text { Seldom }-21 \\
\text { Often - } 8\end{array}$ & $\begin{array}{l}\text { Never }-23 \\
\text { Rarely }-20 \\
\text { Seldom }-41 \\
\text { Often }-16\end{array}$ \\
\hline $\begin{array}{l}\text { Perception of the quality of change in environment } \\
\text { (proportion of positive/negative) }\end{array}$ & $\begin{array}{l}\text { Positive }-63 \\
\text { Negative }-37\end{array}$ & $\begin{array}{l}\text { Positive }-37 \\
\text { Negative }-63\end{array}$ & $\begin{array}{l}\text { Positive }-54 \\
\text { Negative }-46\end{array}$ & $\begin{array}{l}\text { Positive }-48 \\
\text { Negative }-52\end{array}$ & $\begin{array}{l}\text { Positive }-80 \\
\text { Negative }-20\end{array}$ \\
\hline Farm tools owned (nr) & $2.1 \pm 2.4$ & $1.6 \pm 2.0$ & $2.2 \pm 2.1$ & $1.2 \pm 1.7$ & $1.2 \pm 1.6$ \\
\hline Access to honey in the forest (proportion of yes/no) & $\begin{array}{l}\text { Yes }-31 \\
\text { No }-69\end{array}$ & $\begin{array}{l}\text { Yes }-27 \\
\text { No }-73\end{array}$ & $\begin{array}{l}\text { Yes }-26 \\
\text { No }-74\end{array}$ & $\begin{array}{l}\text { Yes }-16 \\
\text { No }-84\end{array}$ & $\begin{array}{l}\text { Yes }-23 \\
\text { No }-77\end{array}$ \\
\hline Mobile phone (proportion of yes/no) & $\begin{array}{l}\text { Yes }-41 \\
\text { No }-59\end{array}$ & $\begin{array}{l}\text { Yes }-34 \\
\text { No }-66\end{array}$ & $\begin{array}{l}\text { Yes }-33 \\
\text { No }-67\end{array}$ & $\begin{array}{l}\text { Yes }-25 \\
\text { No }-75\end{array}$ & $\begin{array}{l}\text { Yes }-39 \\
\text { No }-61\end{array}$ \\
\hline
\end{tabular}

For some variables, "nr" means number, for example number of sharecropped fields, or number of livestock owned. For education of household head, "ordinal categories" refer to ordinal categories of educational attainment in which No education $=0$, Adult education or special education $=1$, Grades $1-$ $6=2$, Grades $7-12=3$, and Grades 13 and above $=4$

livelihood activities included maintaining a home garden, production of legumes, milk, honey and engagement in other income-generating activities.

Clustering of households according to livelihood strategies corresponded well with the PCA ordination plot suggesting robustness of groupings (Fig. 2a). Each point in Fig. 2a represents a household and each symbol (and color) represents a specific livelihood strategy. The nearness of households with the same livelihood strategy in the PCA plot indicates consistency of groupings between cluster analysis and PCA. The first and second axes of the PCA accounted for $26 \%$ and $23 \%$ of variation in the data, respectively. The first principal component had the highest correlations with the variables 'coffeeyield' (0.85), 'maizeyield' (0.35), and 'sorghumyield' $(0.27)$. The second principal component had the highest correlations with 'sorghumyield' $(-0.84)$, 'teffyield' $(-0.40)$ and 'coffeeyield' (0.31) (Table 4). These correlations in the PCA indicated by the longer arrows (Fig. 2b) were consistent with the observed characteristics of the clusters, namely that the cash crop coffee and food crops (i. e. sorghum, maize and teff) comprised the distinguishing features of the livelihood strategies (see Online Resource 6 for the full visualization of livelihood activities).

\subsection{Associations between capital assets and livelihood strategies}

In general, 'coffeeplot' and 'fieldsize' were the capital assets with the strongest associations with the livelihood strategies (Fig. 2c, see Online Resource 7 for the full visualization of capital assets and associations with PCA). This suggests that the ability of households to undertake the production of food crops and cash crops was strongly associated with their access to coffee plot and the size of their farmland. This was consistent with the multinomial logistic regression, which tested for relationships between livelihood strategies and capital assets 
Table 3 Main crops, mean harvest $(\mathrm{kg})$ per household, percentage of harvest used for subsistence and percentage of harvest sold. Khat is an important livelihood variable. However, because respondents were unable to give reliable data on quantity of harvest or income due to mechanism of harvest and selling, we used presence-absence data for this variable

\begin{tabular}{|c|c|c|c|}
\hline Main crops & $\begin{array}{l}\text { Mean harvest }(\mathrm{kg}) \\
\text { per household } \pm \\
\text { standard deviation }\end{array}$ & $\begin{array}{l}\text { Percentage of } \\
\text { harvest used } \\
\text { for subsistence }\end{array}$ & $\begin{array}{l}\text { Percentage of } \\
\text { harvest sold }\end{array}$ \\
\hline Maize & $285 \pm 459$ & 93 & 7 \\
\hline Teff & $100 \pm 153$ & 98 & 2 \\
\hline Sorghum & $84 \pm 157$ & 95 & 5 \\
\hline Barley & $11 \pm 37$ & 99 & 1 \\
\hline Wheat & $10 \pm 39$ & 100 & 0 \\
\hline Coffee & $170 \pm 320$ & 23 & 77 \\
\hline Khat & $\begin{array}{l}131 \text { households } \\
\text { had khat }\end{array}$ & $\begin{array}{c}\text { Some khat was } \\
\text { used by the } \\
\text { households }\end{array}$ & $\begin{array}{l}\text { Most khat was } \\
\text { produced for } \\
\text { the local marke }\end{array}$ \\
\hline
\end{tabular}

and identified significant relationships with 'fieldsize' $(p<0.001)$, 'coffeeplot' $(\mathrm{p}<0.001)$, 'livestock' $(p=0.005)$, and 'farmtools' $(p=0.03)$ (Table 5).

In Fig. 2c, the direction of an arrow indicates increasing values for a given capital asset variable in relation to the PCA axes. The length of an arrow indicates the strength of correlation. The plot indicates that capital assets differed in their association with the livelihood strategies $(p<0.01)$. The strategies involving three food crops were associated with having larger fields. The strategy 'three food crops, coffee and khat' had higher access to a range of capital assets. For example, they were more involved in learning with other farmers through informal exchange of information and knowledge. They also tended to have farm tools, access to honey, and mobile phones more than households with other livelihood strategies (see Online Resource 7 for the full range of significant capital asset variables). The livelihood strategy 'three food crops and khat' (lower left hand corner) had higher engagement in sharecropping and had more livestock. The strategies 'two food crops, coffee and khat' and 'one food crop, coffee and khat' were strongly characterized by ownership of coffee plots (upper right hand corner). ${ }^{2}$ Households undertaking these strategies also learned farming techniques through the government's development agents and had the perception that the condition of the environment had been improving. The strategy 'two food crops and khat' (upper left hand corner) did not show strong positive association with any particular capital asset.

\footnotetext{
${ }^{2}$ The widespread practice of sharecropping, including in coffee production, meant that there were households that harvested coffee but did not own coffee plots. We therefore included 'coffeeplot' in our examination of the links between capital assets and livelihood strategies. That ownership of 'coffeeplot' turned out to be a predictor of coffee strategies was expected, but it was not necessarily inevitable due to sharecropping arrangements.
}

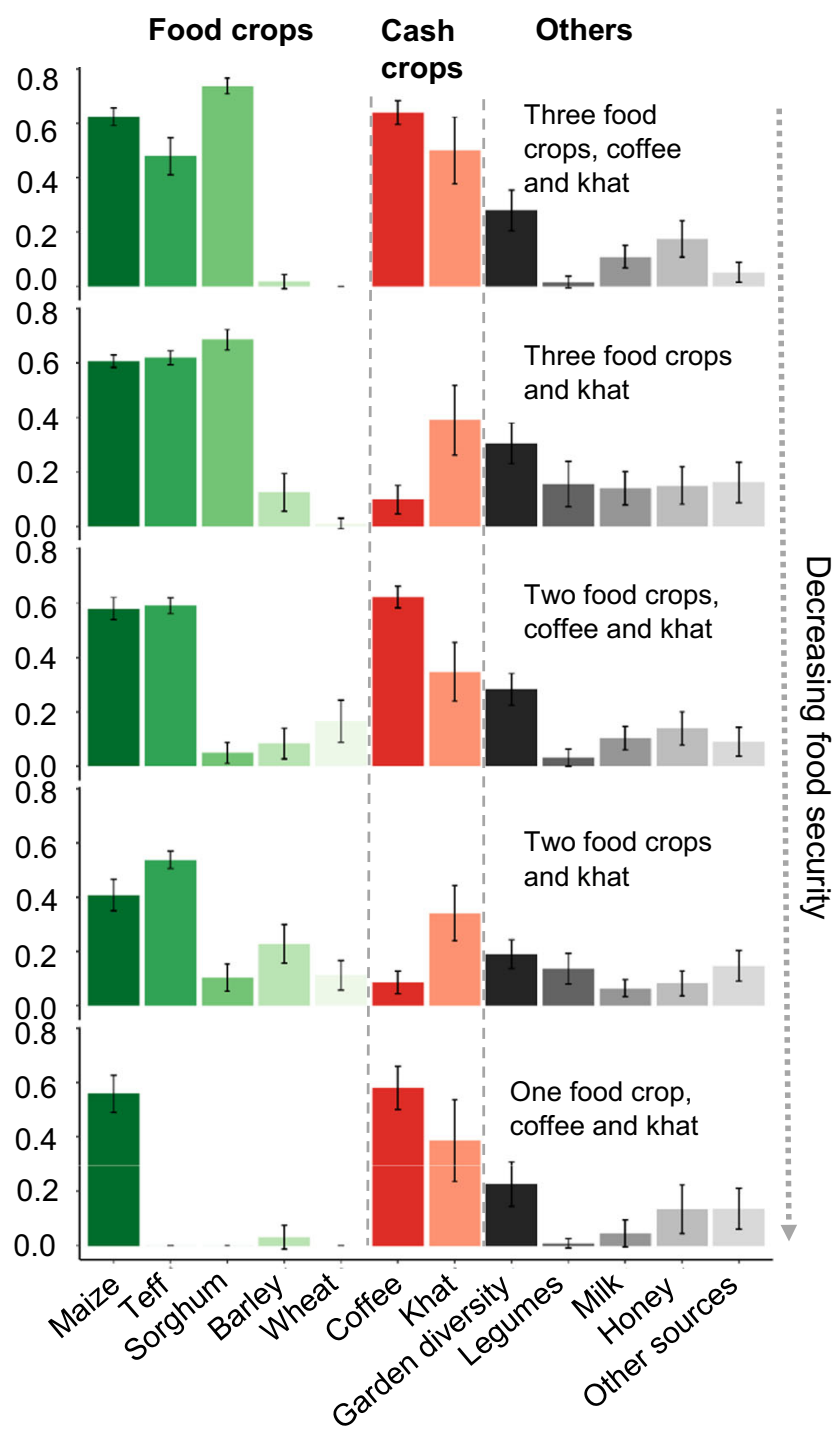

Fig. 1 Livelihood profiles. The $\mathrm{x}$-axis shows livelihood activities in the study area. The y-axis indicates livelihood components. Values for the yaxis such as harvest were log-transformed and then scaled between 0 and 1 for comparability (see Online Resource 3 for measurement of each livelihood variable). Error bars indicate $95 \%$ confidence intervals

In summary, livelihood strategies with coffee were associated with having access to coffee plots. Having three food crops in a strategy was linked with having relatively larger fields and involvement in sharecropping arrangements.

\subsection{Food security and explanatory variables}

Food security, as measured by HFIAS scores, was significantly associated with the types of livelihood strategies at $p=0.03$ (Tables 6 and 7). Moreover, Fig. 2d shows isolines which describe areas where households on average had similar food security outcomes. This visualization shows that households undertaking livelihood strategies with a higher number of food crops (lower right hand corner) were more 
Fig. 2 Ordination plots of livelihood strategies with associated capital assets and food security outcomes. Underlying all four panels are the combined principal component analysis (PCA) and the cluster analysis of livelihood variables with each data point representing a household and a corresponding livelihood strategy indicated by a symbol. The $\mathrm{x}$-axis always depicts the first principal component (26\% explained variation) and the y-axis the second principal component ( $23 \%$ explained variation). a Distribution of households by livelihood strategies in the ordination space of the PCA. $\mathbf{b}$ PCA plot of livelihood activities highlighting the variables that most strongly correlated with the first two axes. Longer arrows suggest stronger correlations with PCA axes. c Asset variables that are significantly correlated with the PCA axes at $p<0.01$ (permutation test). Longer arrows also suggest stronger correlations with PCA axes. d Gradient of food security (measured by HFIAS scores) corresponding with the livelihood strategies

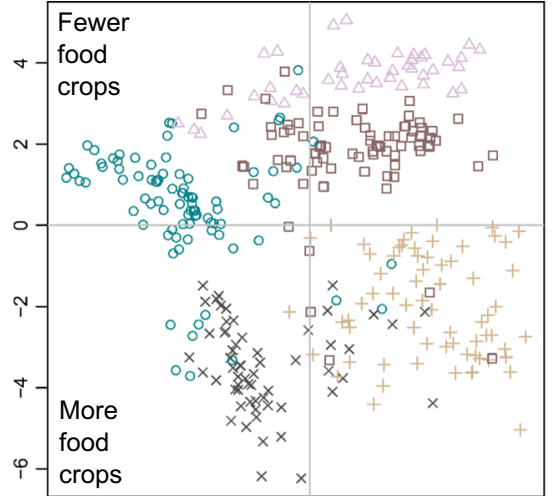

(Fig 2a)

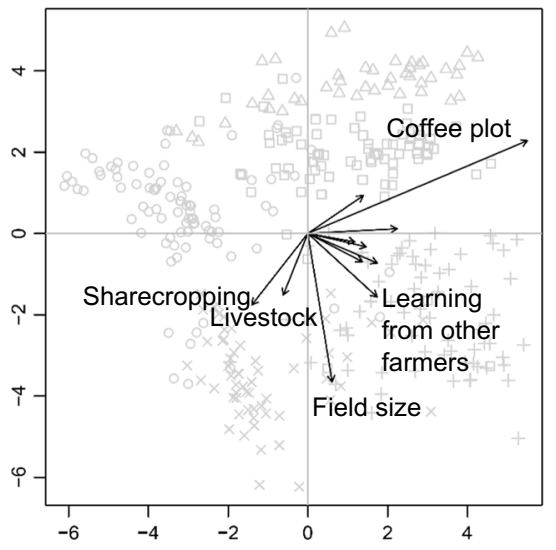

(Fig 2c)

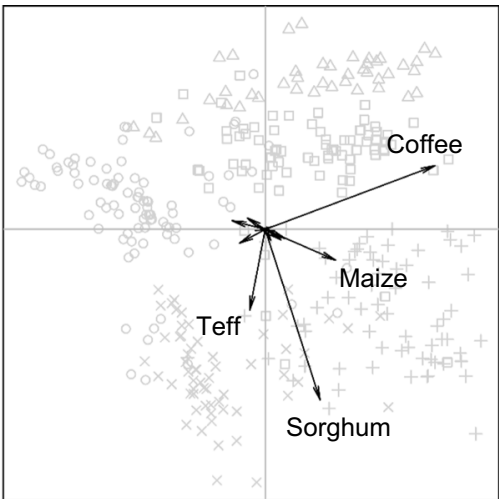

(Fig 2b)

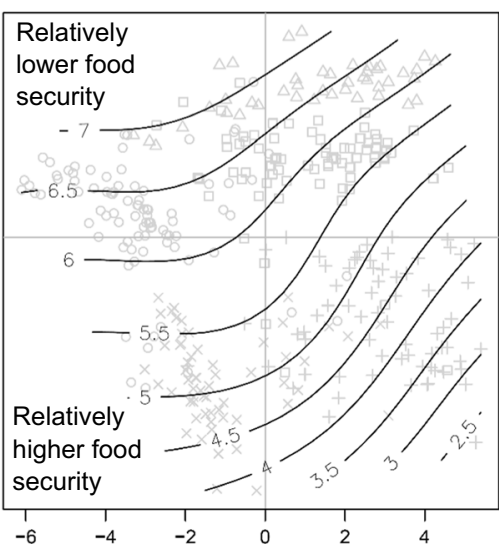

(Fig 2d)

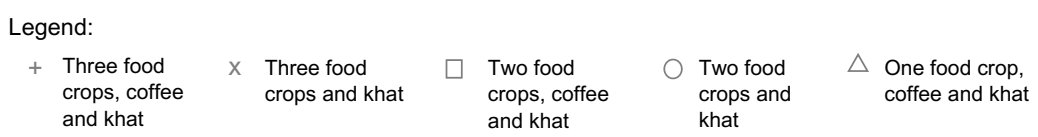

food secure than those with a lower number of food crops (upper left hand corner).

Undertaking livelihood strategies with diverse food crops particularly maize, teff and sorghum complemented with coffee

Table 4 Livelihood activities and PCA loadings

\begin{tabular}{lll}
\hline Livelihood variables & Principal component 1 & Principal component 2 \\
\hline maizeyield & 0.35 & -0.15 \\
teffyield & -0.077 & -0.40 \\
sorghumyield & 0.27 & -0.84 \\
barleyyield & -0.17 & 0.042 \\
wheatyield & -0.089 & 0.056 \\
coffeeyield & 0.85 & 0.31 \\
khat & 0.020 & -0.0028 \\
gardendiversity & 0.079 & -0.051 \\
legumes & -0.13 & -0.068 \\
milk_liter & 0.028 & -0.054 \\
honey_kg & 0.10 & -0.045 \\
oth.income & -0.022 & 0.0022 \\
\hline
\end{tabular}

and khat was linked with being food secure. Having only maize, or maize and teff, even in combination with coffee and khat, was associated with lower food security. Livelihood

Table 5 ANOVA table of multinomial logistic regression applied to capital asset variables against livelihood strategies

\begin{tabular}{llll}
\hline Capital assets & LR Chisq & Degrees of freedom & $P$ value \\
\hline livestock & 14.72 & 4 & $0.0053^{* *}$ \\
mobilephone & 1.87 & 4 & 0.76 \\
farmtools & 11.07 & 4 & $0.025^{*}$ \\
learn_DAs & 5.18 & 4 & 0.27 \\
learn_- & 5.94 & 4 & 0.20 \\
$\quad$ farmers & 7.58 & 4 & 0.11 \\
sharecrop & 227.10 & 4 & $<0.001^{* * *}$ \\
coffeeplot & 6.26 & 4 & 0.18 \\
envichange & 5.13 & 4 & 0.27 \\
accesshoney & 1.37 & 4 & 0.85 \\
landrights & 77.49 & 4 & $<0.001^{* * *}$ \\
fieldsize & $6 * 6$ & & \\
\hline
\end{tabular}

Significant codes: 0 ‘***’ 0.001 “**’ 0.01 '*’ 0.05 ' 1 
Table 6 Independent variables tested against household food insecurity access scale (HFIAS) score, a measure of household food security, and their expected relationships with food security. Low HFIAS scores mean households are more food secure, while high scores mean households are less food secure

\begin{tabular}{|c|c|c|c|}
\hline Independent variables & Type of variable & Expected relationships & References \\
\hline Livelihood strategy & Categorical & $\begin{array}{l}\text { Households with more diverse livelihood strategies will tend } \\
\text { to be more food secure. }\end{array}$ & Pellegrini and Tasciotti 2014 \\
\hline Gender of household head & Categorical & $\begin{array}{l}\text { Male headed-households will tend to be more food secure due } \\
\text { to systematic gendered privilege. }\end{array}$ & Quisumbing et al. 2015 \\
\hline Age of household head & Discrete & $\begin{array}{l}\text { Households with older household head will tend to be less } \\
\text { food secure due to reduction in available labor. }\end{array}$ & Zakari et al. 2014 \\
\hline Education of household head & Ordinal & $\begin{array}{l}\text { Households with more educated household head will tend to } \\
\text { be more food secure due to better knowledge, connections, } \\
\text { and opportunities. }\end{array}$ & Ogundari 2014 \\
\hline $\begin{array}{l}\text { Number of ill household } \\
\text { members }\end{array}$ & Discrete & $\begin{array}{l}\text { Households with more ill household members will tend to be } \\
\text { less food secure because of reduction in available farm } \\
\text { labor and/or medical expenses. }\end{array}$ & Espitia et al. 2018 \\
\hline Kebele & Confounding/categorical & Kebele will have no significant effect & - \\
\hline Survey date & Discrete & Survey date will have no significant effect & - \\
\hline
\end{tabular}

strategies with more food crops were, on average, associated with higher food security outcomes (Figs. 2d, 3 and Online Resource 8). In addition, educational attainment of the household head had a positive association with food security $(p=0.02)$. Gender of household head was also significantly associated $(p=0.03)$. Male headed- households tended to have better food security than female-headed households. Other explanatory variables tested in the model, including survey date, age of household head, household size, number of ill household members, and kebele did not show any significant association.

\section{Discussion}

Our study identified five types of livelihood strategies following a gradient in composition of food and cash crops.

Table 7 ANOVA table of generalized linear model. The response variable is household food security measured through household food insecurity access scale (HFIAS) scores. The independent variable livelihood strategy is a categorical variable that represents the five

\begin{tabular}{llll}
\hline Independent variables & Sum of squares & Degrees of freedom & F value \\
\hline Livelihood strategy & 25.82 & 4 & 2.66 \\
Gender of household head & 11.68 & 1 & $0.032^{*}$ \\
Survey date & 1.76 & 1 & $0.029^{*}$ \\
Age of household head & 1.52 & 1 & 0.73 \\
Educational attainment of household head & 24.67 & 1 & 0.62 \\
Household size & 0.41 & 1 & 3.39 \\
Number of ill household members & 0.58 & 1 & 0.17 \\
Kebele & 22.70 & 5 & 0.24 \\
Residuals & 750.21 & 309 & $0.018^{*}$ \\
\hline
\end{tabular}

Significant codes: 0 '***’ 0.001 '**’ 0.01 '*’ $0.05^{\prime}$ ' 1
Households pursued livelihood diversification mainly in the form of crop diversification. This is somewhat at odds with the trajectories envisaged in agricultural policies in Ethiopia and other developing countries, which prioritize production of cash crops (and food crops for commercial purposes) as a pathway for development and food security. The dissimilarity between these identified local livelihood strategies and the strategies endorsed and supported by policies is notable (Arce 2003) because evidence on the food security benefits of livelihood shifts to cash crop production has been varied and conflicting. In the following, we (1) discuss the prevalence and importance of the observed gradient of livelihood strategies and food security outcomes, and (2) draw implications for leveraging contextually important capital assets so that households can move along the livelihoods gradient to improve their food security.

livelihood strategies identified (i. e. 'three food crops, coffee and khat', 'three food crops and khat', 'two food crops, coffee and khat', 'two food crops and khat', and 'one food crop, coffee and khat') 


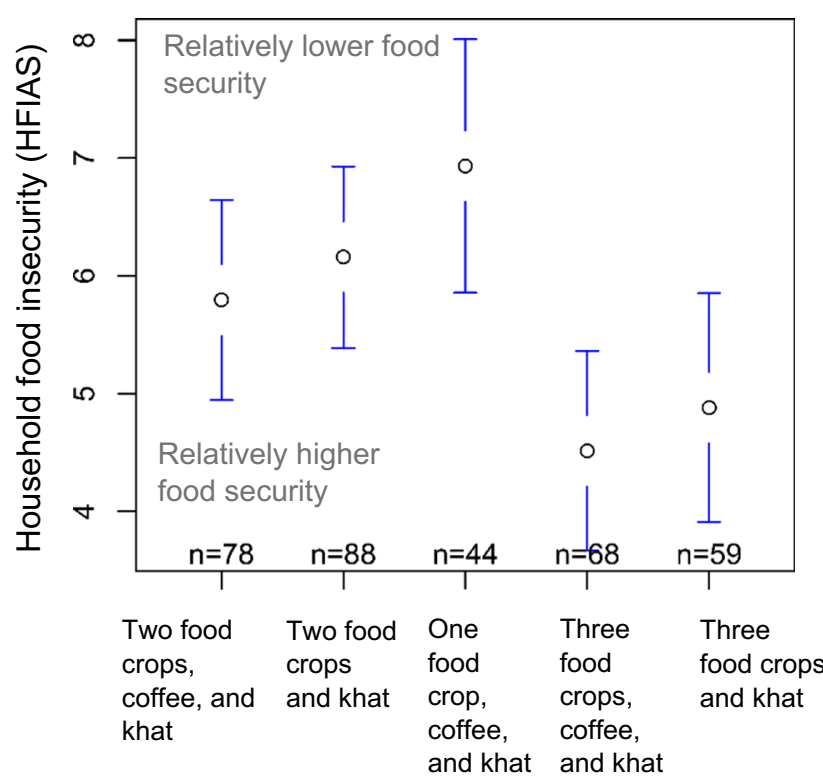

Fig. 3 Plot of means of HFIAS scores by livelihood strategy. Error bars indicate standard error

\subsection{Gradient of livelihood strategies and food security}

Ellis (2000) discussed the importance of livelihoods diversification in a context characterized by precarious conditions and a need for survival. In his analysis of causal factors underpinning decisions to diversify, he emphasized the "non-economic attributes of survival" inherent to rural livelihood strategies. We conjecture that for households in southwest Ethiopia, the feature of diverse crops in the livelihood strategies may be motivated not so much by economic profitability and capital asset accumulation but by the basic need to ensure households' direct access to food.

The observed importance of diverse food crops in local livelihood strategies is consistent with the findings of Fafchamps (1992), who observed the critical importance of staple consumption for survival. Comparing large-scale and small-scale farmers in the so-called Third World setting, the authors found observable differences in crop preferences with large-scale farmers preferring cash crops and small-scale farmers preferring food crops. For small-scale farmers, food self-sufficiency through food crop production was found to be the best approach for assuring food security, even when food markets were present. A recent study in the Eastern Cape, South Africa, also found that household food production for the purpose of household consumption resulted in lower levels of hunger. Although wage income was considered important, household food production was critical for addressing the immediacy of food security concerns (Rogan 2018). Similarly, in our study, cash crops played an important role in income generation. Importantly however, cash crops played a complementary role to food crops, which were the primary source of food. With combinations of diverse food and cash crops, households in southwest Ethiopia were able to take advantage of what Ellis (2000) termed "complementarities between crops". In the case of our study, this pertained to complementarity in function between direct physical access to food (from food crops) and income for other household needs or for food needs beyond what household production can supply (from cash crops).

Our study showed that combinations of food crops and cash crops, particularly diverse food crops, were important for the food security of households. Comparing the two livelihood strategies with the strongest contrast in food security status (i.e. 'three food crops, coffee and khat' and 'one food crop, coffee and khat') suggests that households that tend to be more food insecure could theoretically increase their food security by increasing the diversity of food crops they produce (Fig. 2d). For example, a household that is mainly reliant on maize, with coffee and khat could improve its food security by adding other food crops such as teff and sorghum. This underscores a pathway to food security that is distinct from the market-oriented pathway of the Ethiopian agricultural policy. It is a pathway that emerges from the semi-subsistence production and consumption practices of the households in the area. In a study in Malawi, Radchenko and Corral (2018) found varied effects of agricultural commercialization on nutritional outcomes for households in different tiers of the population - benefitting some and harming others. Malawian households were likely to focus on food crops when they expected food insecurity and malnutrition. However, under conditions of weaker market barriers, households were likely to choose cash crops. These findings may also explain the preponderance of diverse food crops in southwest Ethiopia, which has been similarly characterized by seasonal food insecurity (Ethiopia CSA and WFP 2014) and limited market access. Findings by other researchers have also identified market access and infrastructure (e.g. transportation) as important contextual factors that influence the choice and outcomes of crop production (Fafchamps 1992; Radchenko and Corral 2018). A limitation of our household level investigation was that we did not include a systematic analysis of these contextual factors and the logic underpinning households' strategies in view of these factors. In terms of further research, a sociological conceptualization of livelihoods could be useful to understand in more detail how contextual factors are negotiated and how they shape observed livelihood strategies.

\subsection{Supporting local livelihoods: leveraging contextually important capital assets}

Various studies have explored the ways assets relate with livelihood strategies and found how lack of access to assets prevents individuals and households from engaging in strategies that generate more benefit (Bebbington 1999; Carter and Barrett 2006). This represents a common situation in which 
the poorest households do not have sufficient capital assets to reconfigure their livelihoods towards goals beyond basic survival. In our study area, households that had larger areas of farmland were able to engage in the strategy that had high diversity in food and cash crops, which subsequently generated better food security outcomes. They also had access to a wider range of capital assets. Supporting households to pursue livelihood strategies with diverse food and cash crops thus should be cognizant of the need to address shortages in capital assets.

Most notably, the field size that households were entitled to, turned out to be strongly correlated with livelihood strategies. Presently, land ownership in Ethiopia rests with the government and individuals hold usufruct rights to land. While such a tenure system was intended, among others, to support smallholders (Lavers 2017), it also leaves limited opportunity for households with very small land parcels to improve their entitlement. Households that were able to pursue livelihood strategies with three food crops, had on average, a hectare of land in contrast with households that undertook the strategy 'one food crop, coffee, and khat' with only a third of a hectare. The challenge of small land holdings is likely to further increase due to rapid population growth, with smaller parcels of land being inherited by each subsequent generation (Gebrehiwot et al. 2016). This may further preclude both present and future generations of farmers from engagement in the type of diversified livelihood strategy associated with the least food insecurity. Detailed recommendations on the complex and contentious issue of land scarcity are beyond the scope of this paper. At a basic level, however, and in view of landgrabbing in various parts of Ethiopia (Ango 2018), opening space for debate at the policy level, and exploring options for land sufficiency at the household level should at least be taken up; possibly alongside culturally appropriate efforts to address population growth. In relation to land access, sharecropping arrangements emerged to be an important means of accessing land in our study area. Households that were engaged in livelihood strategies involving one to two food crops and had lower food security, were not as much engaged in sharecropping as those producing three food crops. Investigating the factors that underlie Ethiopian sharecropping arrangements including input contribution, risk distribution, and benefit distribution may be an important step for understanding and exploring contextually suitable options for strengthening and embedding equity in these arrangements.

Furthermore, food security was not only influenced by livelihood strategies, but also by other household characteristics such as gender and educational attainment of the household head. Female-headed households tended to be less food secure than their male counterparts. This is in line with findings from gender and development research that examined systematic inequality around access and control of capital assets (Quisumbing et al. 2015) and decision-making processes (e. g. Sumner et al. 2017) causing serious disadvantage among female heads of households. In other parts of Ethiopia, women's social ties have been found to be less linked to the formal economy (Torkelsson 2007); and they have less control and access to important assets such as land and labor (Quisumbing et al. 2015). Improvements to gender equality thus emerge as an important precondition for achieving food security (Njuki et al. 2016).

Unlike other studies, we found no significant relationship between household size and food security. This could be because, in this context, household size is important for labor, but may also be negatively related to food availability because of more household members to feed (e. g. Feleke et al. 2005; Akinboade and Adeyefa 2018). Age of household head was similarly not significantly related to food security. Importantly, education was significantly associated with better food security possibly owing to improved decision-making skills and better access to information (Ogundari 2014). In summary, our findings thus suggest that access to land, fair sharecropping arrangements, gender equality, and education are foundational requirements for food security in southwest Ethiopia.

\section{Conclusion}

Based on the observed farming practices in the study area, diversified production of both food and cash crops should be encouraged to improve food security. Policies that seek to promote food security of smallholder farming households would do well to recognize and support the complementarities between food crops and cash crops rather than impose a narrowly framed economic growth narrative that can potentially erode these complementarities. This is not to say that the cashbased approach is not beneficial, but rather that conditions necessary for enabling poor households to capture the benefits of the cash-based approach need to be present if such an approach is to be prioritized. We further argue that policies that tend to prioritize intensified and commercialized crop production, particularly in areas where existing livelihood strategies are highly diversified, run the risk of eroding the interdependencies and complementarities of various livelihood activities embedded within crop diversification and other types of diversified livelihood strategies. Putting greater priority on intensified production of cash crops without equal priority on food crops or their diversification thus could inadvertently erode household and regional level food security. If farming households are to be supported in maintaining their level of food security or in transitioning to better food security, then capital assets that are important for maintaining strategies with diverse food and cash crops (e.g. three food crops, coffee and khat) should be given priority attention. Supporting farming households to shift towards livelihood strategies associated 
with better food security outcomes should consider the elements embedded in households' current strategies and support them in accessing those capital assets they need to expand the sphere of their means and goals (Rakodi 1999).

Acknowledgments We are grateful to the local residents of the study area who generously shared time and information during the survey, to Shiferaw Diriba and Olead Amente who worked as translators, and to Dave Abson, Neil Collier, and Kristoffer Hylander for helpful comments. We thank Feyera Senbeta for facilitating our research and helpful discussions. Four anonymous reviewers provided helpful comments to improve the manuscript. This study was funded by a European Research Council (ERC) consolidator grant to JF.

Funding This research work received funding from the European Research Council under the EU's 7th Framework Programme with project ID 614278.

\section{Compliance with ethical standards}

Conflict of interest All authors declare no conflict of interest involved in this work.

Informed consent All respondents involved provided consent to participate in the survey.

Ethical approval Prior to data collection, the survey protocol was formally cleared by the ethics committee of Leuphana University Lueneburg.

Open Access This article is distributed under the terms of the Creative Commons Attribution 4.0 International License (http:// creativecommons.org/licenses/by/4.0/), which permits unrestricted use, distribution, and reproduction in any medium, provided you give appropriate credit to the original author(s) and the source, provide a link to the Creative Commons license, and indicate if changes were made.

\section{References}

Acheampong, E. O., Sayer, J., \& Macgregor, C. J. (2018). Road improvement enhances smallholder productivity and reduces forest encroachment in Ghana. Environmental Science and Policy, 85, 64 71.

Achterbosch, T., van Berkum, S., \& Meijrink, G. (2014) Cash crops and food security: contributions to income, livelihood risk and agricultural innovation. No. 2014-15, LEI Wageningen UR.

Akinboade, O. A., \& Adeyefa, S. A. (2018). An analysis of variance of food security by its main determinants among the urban poor in the city of Tshwane, South Africa. Social Indicators Research, 137(1), $61-82$.

Ango, T. G. (2018). "Medium-scale" forestland grabbing in the southwestern highlands of Ethiopia: Impacts on local livelihoods and forest conservation. Land, 7(1), 24.

Arce, A. (2003). Value contestations in development interventions: Community development and sustainable livelihoods approaches. Community Development Journal, 38(3), 199-212.

Bebbington, A. (1999). Capitals and capabilities: A framework for analyzing peasant viability, rural livelihoods and poverty. World Development, 27(12), 2021-2044.
Belsky, J., \& Siebert, S. (2003). Cultivating cacao: Implications of sungrown cacao on local food security and environmental sustainability. Agriculture and Human Values, 20(3), 277-285.

Bonnin, C., \& Turner, S. (2012). At what price rice? Food security, livelihood vulnerability, and state interventions in upland northern Vietnam. Geoforum, 43(1), 95-105.

Carney, D. (1999) Approaches to sustainable livelihood for the rural poor. Working Paper ODI Poverty Briefing 2. Overseas Development Institute, London.

Carter, M., \& Barrett, C. (2006). The economics of poverty traps and persistent poverty: An asset-based approach. Journal of Development Studies, 42(2), 178-199.

Chambers, R. (1987) Sustainable livelihoods, environment, and development: putting poor rural people first. IDS Discussion Paper. No. 240. Institute of Development Studies, UK.

Chambers, R., \& Conway, G. (1992). Sustainable rural livelihoods: Practical concepts for the $21^{\text {st }}$ century. UK: Institute of Development Studies.

Chambers, R., \& Ghildyal, B. P. (1985). Agricultural research for resource-poor farmers: The farmer-first-and-last model. Agricultural Administration, 20(1), 1-30.

Coates, J., Swindale, A., \& Bilinsky, P. (2007). Household food insecurity access scale (HFIAS) for measurement of food access: Indicator guide. Food and nutrition technical assistance project. Washington, DC: Academy for Educational Development.

De Haan, L., \& Zoomers, A. (2006). How to research the changing outlines of African livelihoods. Africa Development, 31(4), 121150.

Ellis, F. (2000). The determinants of rural livelihood diversification in developing countries. Journal of Agricultural Economics, 51(2), 289-302.

Espitia, P. J. P., Lissbrant, S., \& Moyano-Tamara, L. (2018). Social and cultural perceptions regarding food security and health in the departments of Bolivar and La Guajira, in the Caribbean region of Colombia. Journal of Hunger and Environmental Nutrition, 13(2), 255-276.

Ethiopia Central Statistical Agency, \& World Food Program. (2014) Comprehensive Food Security and Vulnerability Analysis. URL: http://documents.wfp.org/stellent/groups/public/documents/ena/ wfp265490.pdf. Accessed 10 November 2016.

Ethiopia National Planning Commission. (2016) The Second Growth and Transformation Plan.

Fafchamps, M. (1992). Cash crop production, food price volatility, and rural market integration in the third world. American Journal of Agricultural Economics, 74(1), 90-99.

Feleke, S. T., Kilmer, R. L., \& Gladwin, C. H. (2005). Determinants of food security in southern Ethiopia at the household level. Agricultural Economics, 33(3), 351-363.

Food and Agriculture Organization. (2016). Ethiopia at a glance. URL: http://www.fao.org/ethiopia/fao-in-ethiopia/ethiopia-at-a-glance/ en/. Accessed 10 November 2016.

Frison, E., Cherfas, J., \& Hodgkin, T. (2011). Agricultural biodiversity is essential for a sustainable improvement in food and nutrition security. Sustainability, 3(1), 238-253.

Gebrehiwot, M., Elbakidze, M., Lidestav, G., Sandewall, M., Angelstam, P., \& Kassa, H. (2016). From self-subsistence farm production to khat: Driving forces of change in Ethiopian agroforestry homegardens. Environmental Conservation, 43(3), 263-272.

Gebreyesus, S., Lunde, T., Mariam, D., Woldehanna, T., \& Lindtjorn, B. (2015). Is the adapted household food insecurity access scale (HFIAS) developed internationally to measure food insecurity valid in urban and rural households of Ethiopia? BMC Nutrition, 1(1), 2.

Govereh, J., \& Jayne, T. (2003). Cash cropping and food crop productivity: Synergies or tradeoffs? Agricultural Economics, 28(1), 39-50. 
Hylander, K., Nemomissa, S., Delrue, J., \& Enkosa, W. (2013). Effects of coffee management on deforestation rates and forest integrity. Conservation Biology, 27(5), 1031-1040.

Jones, A. (2014). The production diversity of subsistence farms in the Bolivian Andes is associated with the quality of child feeding practices as measured by a validated summary feeding index. Public Health Nutrition, 18(2), 329-342.

Jones, A., Shrinivas, A., \& Bezner-Kerr, R. (2014). Farm production diversity is associated with greater household dietary diversity in Malawi: Findings from nationally representative data. Food Policy, $46,1-12$.

Kidanewold, B. B., Seleshi, Y. \& Melesse, A. M. (2014) Surface water and groundwater resources of Ethiopia: Potentials and challenges of water resources development. Nile River Basin. Springer International Publishing, 97-117.

Lam, R. D., Boafo, Y. A., Degefa, S., Gasparatos, A., \& Saito, O. (2017). Assessing the food security outcomes of industrial crop expansion in smallholder settings: Insights from cotton production in northern Ghana and sugarcane production in Central Ethiopia. Sustainability Science, 12(5), 677-693.

Lang, T., \& Barling, D. (2012). Food security and food sustainability: Reformulating the debate. Geographical Journal, 178(4), 313-326.

Lavers, T. (2017). Land registration and gender equality in Ethiopia: How state-society relations influence the enforcement of institutional change. Journal of Agrarian Change, 17(1), 188-207.

Levine, S. (2014) How to study livelihoods: bringing a sustainable livelihoods framework to life. Working Paper 22. Secure Livelihoods Research Consortium, Overseas Development Institute, London.

Lin, B. (2011). Resilience in agriculture through crop diversification: Adaptive management for environmental change. BioScience, 61(3), 183-193.

Loison, S. A. (2015). Rural livelihood diversification in sub-Saharan Africa: A literature review. The Journal of Development Studies, 51(9), 1125-1138.

M'Kaibi, F., Steyn, N., Ochola, S., \& Plessis, L. D. (2015). Effects of agricultural biodiversity and seasonal rain on dietary adequacy and household food security in rural areas of Kenya. BMC Public Health, 15(1), 422

Martin, S., Lorenzen, K., \& Bunnefeld, N. (2013). Fishing farmers: Fishing, livelihood diversification and poverty in rural Laos. Human Ecology, 41(5), 737-747.

Maxwell, S., \& Fernando, A. (1989). Cash crops in developing countries: The issues, the facts, the policies. World Development, 17(11), $1677-1708$

Maxwell, D., Coates, J., \& Vaitla, B. (2013) How do different indicators of household food security compare? Empirical evidence from Tigray. Feinstein International Center.

Nichols, C. (2015). Shifting production/shifting consumption: A political ecology of health perceptions in Kumaon, India. Geoforum, 64, 182-191.

Njuki, J., Parkins, J. R., \& Kaler, A. (Eds.). (2016). Transforming gender and food security in the global south. New York: Routledge.

O'Brien, K., \& Leichenko, R. (2000). Double exposure: Assessing the impacts of climate change within the context of economic globalization. Global Environmental Change, 10(3), 221-232.

Ogundari, K. (2014). The paradigm of agricultural efficiency and its implication on food security in Africa: What does meta-analysis reveal? World Development, 64, 690-702.

Oksanen, J., Blanchet, G., Kindt, R., Legendre, P., Minchin, P., O'Hara R. B., Simpson, G., Solymos, P., Stevens, M. H., \& Wagner, H. (2016) Vegan: Community ecology package. $\mathrm{R}$ package version $2.3-4$. https://CRAN.R-project.org/package=vegan.
Pellegrini, L., \& Tasciotti, L. (2014). Crop diversification, dietary diversity and agricultural income: Empirical evidence from eight developing countries. Canadian Journal of Development Studies/Revue canadienne d'études du développement, 35(2), 211-227.

Pingali, P. (2012). Green revolution: Impacts, limits, and the path ahead. Proceedings of the National Academy of Sciences, 109(31), 12302 12308.

Powell, B., Thilsted, S. H., Ickowitz, A., Termote, C., Sunderland, T., \& Herforth, A. (2015). Improving diets with wild and cultivated biodiversity from across the landscape. Food Security, 7(3), 535-554.

Quisumbing, A. R., Rubin, D., Manfre, C., Waithanji, E., van den Bold, M., Olney, D., Johnson, N., \& Meinzen-Dick, R. (2015). Gender, assets, and market-oriented agriculture: Learning from high-value crop and livestock projects in Africa and Asia. Agriculture and Human Values, 32(4), 705-725.

R Development Core Team. (2008) R: A language and environment for statistical computing. R Foundation for Statistical Computing, Vienna, Austria. ISBN 3-900051-07-0, URL: http://www.Rproject.org

Radchenko, N., \& Corral, P. (2018). Agricultural commercialization and food security in rural economies: Malawian experience. The Journal of Development Studies, 54(2), 256-270.

Rakodi, C. (1999). A capital assets framework for analysing household livelihood strategies: Implications for policy. Development Policy Review, 17(3), 315-342.

Rogan, M. (2018). Food poverty, hunger and household production in rural eastern cape households. Development Southern Africa, 35(1), 90-104.

Salazar, L., Gonzales-Flores, M., Aramburu, J., \& Winters, P. (2015) Food security and productivity impacts of technology adoption in small subsistence farmers in Bolivia. IDB Working Paper Series No. IDB-WP-567. Inter-American Development Bank, Washinton DC.

Sayer, J., Ghazoul, J., Nelson, P., \& Boedhihartono, A. K. (2012). Oil palm expansion transforms tropical landscapes and livelihoods. Global Food Security, 1(2), 114-119.

Scoones, I. (1998) Sustainable rural livelihoods: a framework for analysis. Working Paper, vol. 72. Institute for Development Studies, Sussex.

Sibhatu, K. T., \& Qaim, M. (2018). Farm production diversity and dietary quality: Linkages and measurement issues. Food Security, 10(1), 47-59.

Smith, L., El Obeid, A., \& Jensen, H. (2000). The geography and causes of food insecurity in developing countries. Agricultural Economics, 22(2), 199-215.

Sumner, D., Christie, M. A., \& Boulakia, S. (2017). Conservation agriculture and gendered livelihoods in northwestern Cambodia: Decision-making, space and access. Agriculture and Human Values, 34(2), 347-362.

Sunderland, T. C. (2011). Food security: Why is biodiversity important? International Forestry Review, 13(3), 265-274.

Torkelsson, A. (2007). Resources, not capital: A case study of the gendered distribution and productivity of social network ties in rural Ethiopia. Rural Sociology, 72(4), 583-607.

Van Buuren, S., \& Groothuis-Oudshoorn, K. (2011). Mice: Multivariate imputation by chained equations in R. Journal of Statistical Software, 45(3), 1-67.

Venables, W. N., \& Ripley, B. D. (2002) Modern applied statistics with S. Fourth edition. Springer, New York. ISBN 0-387-95457-0.

Von Braun, J. (1995). Agricultural commercialization. Impacts on income and nutrition and implications for policy. Food Policy, 20(3), 187202. 
Vongvisouk, T., Mertz, O., Thongmanivong, S., Heinimann, A., \& Phanvilay, K. (2014). Shifting cultivation stability and change: Contrasting pathways of land use and livelihood change in Laos. Applied Geography, 46, 1-10.

World Bank. (2016) URL: http://data.worldbank.org/indicator/SP.RUR. TOTL.ZS?locations=ET. Accessed: 10 November 2016.

Zakari, S., Ying, L., \& Song, B. (2014). Factors influencing household food security in West Africa: The case of southern Niger. Sustainability, 6, 1191-1202.

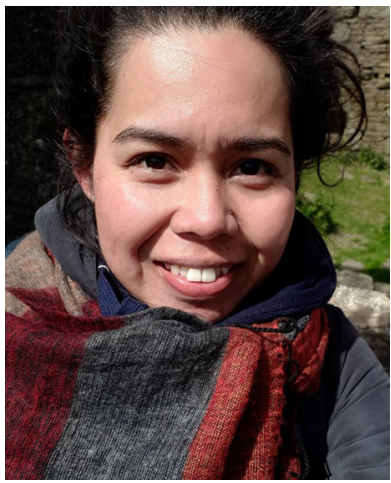

Ms. Aisa O. Manlosa studies the links between livelihood strategies, capital assets, and food security with a particular focus on southwestern Ethiopia. Her interests include how gender norms and power relations influence access to assets and negotiations in the construction of livelihoods at the household and community levels. Currently, she is doing a $\mathrm{PhD}$ contributing to the project "Social-Ecological System Properties Benefiting Biodiversity and Food Security" at Leuphana University Lueneburg in Germany.

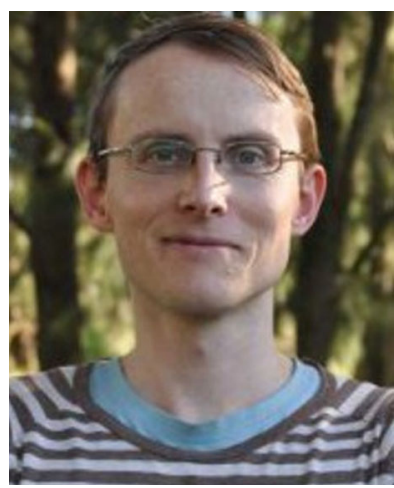

Dr. Jan Hanspach is an ecologist interested in how species respond to environmental conditions and human activities. Driven by the view that the loss of biodiversity and disturbance of ecosystems cannot be solved by ecological research alone, he has been working in transdisciplinary settings with a focus on social-ecological systems. Methodologically, he employs statistical and graphical capabilities in the $\mathrm{R}$ framework.

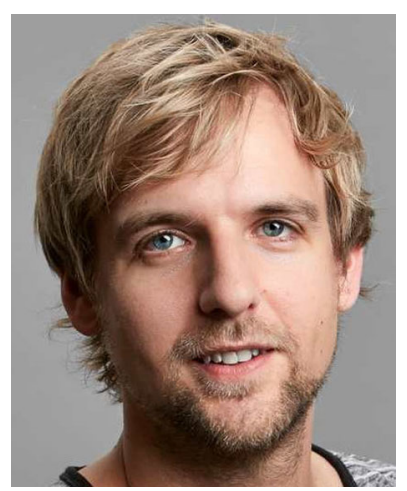

Dr. Jannik Schultner has a background in ecology, biodiversity conservation, and statistics. $\mathrm{He}$ works at the interface of these research areas, applying statistics as a tool for the study of socialecological systems. His current research investigates the bidirectional interactions between people and the environment.

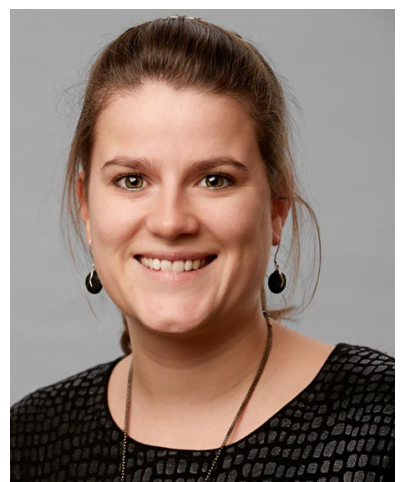

Dr. Ine Dorresteijn is an assistant professor at the Copernicus Institute of Sustainable Development at Utrecht University. She researches biodiversity conservation, humanwildlife interactions, and landscape sustainability science. She currently takes a socialecological systems approach to understand the underlying drivers of human-mammal coexistence.

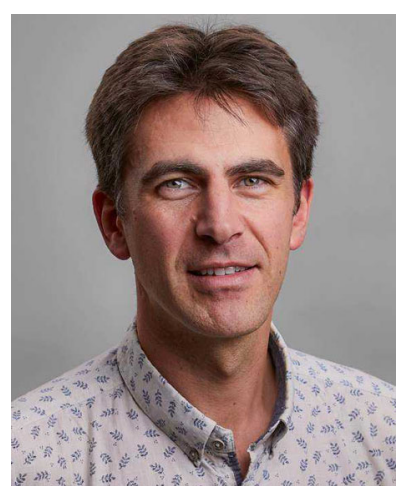

Prof. Joern Fischer works at the Faculty of Sustainability at Leuphana University Lueneburg. Since 2014, he has been leading the project "Social-Ecological System Properties Benefiting Biodiversity and Food Security". His research is problem-oriented and interdisciplinary. He seeks to contribute to an improved conceptual and empirical basis for biodiversity conservation and sustainability science. 